\title{
Kajian Preferensi Masyarakat dan Sikap Pemerintah Terkait Reaktivasi (Penghidupan Kembali) Jalur Kereta Api Semarang - Yogyakarta
}

\author{
Reinaldo Butar Butar ${ }^{1}$ \\ Direktorat Jenderal Perkeretaapian Kementerian Perhubungan \\ Jakarta, Indonesia
}

Artikel Masuk : 9 November 2015

Artikel Diterima : 11 Desember 2015

Tersedia Online : 30 Desember 2015

\begin{abstract}
Abstrak: Lintas Semarang-Magelang-Yogyakarta sepanjang $\pm 130 \mathrm{~km}$ saat ini telah terkoneksi dengan infrastruktur jalan raya. Kondisi ini menjadikan moda transportasi berbasis jalan raya menjadi satu-satunya pilihan moda transportasi yang digunakan oleh masyarakat untuk melakukan perjalanan. Hal ini membuat beberapa ruas jalan yang melintasi BawenAmbarawa-Magelang-Yogyakarta mengalami kepadatan yang berakibat kepada kemacetan. Pemerintah mempunyai kebijakan untuk mereaktivasi (menghidupkan kembali) jalur rel kereta api yang dahulu pernah dioperasikan sebagai moda transportasi lintas SemarangYogyakarta. Apabila kebijakan ini diimplementasikan, masyarakat akan mempunyai alternatif pilihan moda transportasi. Penelitian bertujuan untuk mengkaji preferensi masyarakat dan sikap pemerintah terkait kebijakan reaktivasi jalur rel lintas Semarang - Yogyakarta.Penelitian dilakukan dengan menggunakan metode penelitian campuran kualitatif dan kuantitatif. Analisis dilakukan dengan metode deksriptif kuantitatif dan kualitatif, dimana setelah diperoleh hasil analisis skoring preferensi masyarakat, dilakukan analisis tabulasi silang dan dilanjutkan dengan analisis deskriptif kualitatif. Temuan penelitian menghasilkan bahwa variabel indikator berupa biaya perjalanan, waktu tempuh, aksesibilitas, dan sikap kualitatif (kenyamanan, keamanan, dan keselamatan) mempunyai hubungan keterkaitan dengan preferensi masyarakat untuk beralih menggunakan moda kereta api. Kemudian, ketika preferensi masyarakat tersebut dikomparasikan dengan sikap pemerintah, diperoleh hasil bahwa terdapat kesesuaian antara preferensi masyarakat dan sikap pemerintah untuk variabel indikator sikap kualitatif dan aksesibilitas. Akan tetapi, terkait variabel indikator biaya perjalanan dan waktu tempuh terdapat ketidaksesuaian antara apa yang menjadi preferensi masyarakat dengan apa yang menjadi sikap pemerintah.
\end{abstract}

Kata Kunci: kebijakan reaktivasi, preferensi masyarakat, sikap pemerintah

Abstract: Connected with a roadline of $\pm 130 \mathrm{~km}$ length, the human traffic along Semarang Magelang - Yogyakarta corridor heavily depends on road transportation modes. This creates traffic congestions on particular road strips of Bawen - Ambarawa - Magelang - Yogyakarta. Currently, the government plans to exercise a policy to reactivate the dead railroad between Semarang and Yogyakarta. Once being implemented, it may provide people an alternative choice of transportation mode. The study aimed to assess people's preference and attitude

\footnotetext{
${ }^{1}$ Korespondensi Penulis: Direktorat Jenderal Perkeretaapian Kementerian Perhubungan, Indonesia Email: ranbutbut@gmail.com
} 
toward the policy. This study was conducted using a mixture of qualitative and quantitative research. Descriptive quantitative and qualitative methods were used through scoring analysis of the people's preference, cross tabulation analysis, and qualitative descriptive analysis. The findings revealed that variables of travel cost, travel time, accessibility, and qualitative attitude (comfort, security, and safety) have relations to their preference for the modal switch. Compared to the government attitude, there are only qualitative attitude and accessibility variables which are similar. In terms of travel cost and travel time variables, they actually do not conform each other.

Keywords: reactivation policy, community preferences, government position

\section{Pendahuluan}

Lintas jalan Semarang - Ambarawa - Magelang - Yogyakarta sepanjang $\pm 130 \mathrm{~km}$, merupakan salah satu lintas terpadat yang menghubungkan Provinsi Jawa Tengah dengan Provinsi Daerah Istimewa Yogyakarta. Beberapa ruas jalan raya yang melintasi Bawen Ambarawa - Magelang - Yogyakarta telah mengalami kepadatan yang berakibat pada kemacetan. Berdasarkan proyeksi tahun 2014, rata-rata nilai VCR (Volume Capacity Ratio) sudah berada di atas 0,85 (Direktorat Jenderal Perkeretaapian, 2006). Nilai di atas 0,85 tersebut mengindikasikan kecepatan rendah atau terindikasi mengalami kepadatan lalu lintas. Guna mengurangi beban kepadatan jalan tersebut, pemerintah mempunyai alternatif kebijakan untuk mereaktivasi (menghidupkan kembali) jalur rel kereta api lintas Semarang Yogyakarta. Jalur rel kereta api tersebut sudah ada sejak zaman Pemerintah Belanda dan pernah dioperasikan sebagai jalur transportasi kereta pengangkut hasil panen ke pelabuhan utama di Semarang dan memudahkan Pemerintah Belanda untuk mengawasi daerah perkebunan yang menjadi jajahannya karena jaringan kereta api tersebut terkoneksi dengan fasilitas militer.

Masalah kemacetan telah mendorong beberapa kota besar untuk mengekspansi jaringan kereta api dan membuat jaringan rel baru (Li, Lam, Wong, \& Sumalee, 2011). Namun, terdapat beberapa hal yang perlu dipertimbangkan dalam merencanakan jaringan rel baru, meliputi panjang rel dan jumlah serta lokasi stasiun pemberhentian (Vuchic, 2005; $\mathrm{Li}$ et al., 2011). Panjang rel akan berkaitan dengan cakupan pelayanan, modal, dan biaya operasional. Jaringan rel kereta yang panjang melayani cakupan yang luas namun juga membutuhkan modal dan biaya operasional yang besar. Jaringan rel yang pendek memiliki layanan yang lebih sempit namun modal dan biaya operasional yang kecil serta mempersingkat waktu tempuh perjalanan (Li et al., 2011). Unsur keamanan, jadwal transportasi yang pasti, kecepatan tinggi, dan polusi yang rendah menjadikan model transportasi rel atau kereta perlu dikembangkan (Shuai \& Haiying, 2011). Dalam menyediakan sistem transportasi publik perlu untuk memperhatikan fleksibelitas dan kualitas karena akan mempengaruhi perilaku dan permintaan pengguna (Polat, 2012). Permintaan pengguna transportasi publik dipengaruhi oleh faktor fisik dan perilaku, seperti alternatif integrasi moda yang akan digunakan, siapa pengguna, jarak perjalanan, waktu perjalanan, tujuan perjalanan, frekuensi perjalananan, dan kebijakan pemerintah (Polat, 2012). Lebih lanjut, permintaan transportasi publik juga dipengaruhi oleh harga, intervensi pemerintah, karakteristik geografis, dan perilaku dan pola perjalanan (Albalate \& Bel, 2010). Serupa dengan Souche (2010) yang juga mengungkapkan bahwa biaya perjalanan akan sangat mempengaruhi pemilihan moda transportasi. Pelayanan transportasi umum mempengaruhi pemilihan moda (Matas, 2004; Crotte, 2008; Polat, 2012).

Sistem transportasi berkaitan dengan hampir setiap aspek dari aktivitas manusia yang hendaknya menjadi suatu kesatuan yang menyebar, terintegrasi, dan berkelanjutan. Bosserhoff (2007) mengungkapkan bahwa penggunaan transportasi 
berfungsi sebagai penghubung antar wilayah. Dalam pemilihan moda transportasi, baik itu masyarakat sebagai pengguna jasa maupun pemerintah sebagai penyedia jasa transportasi mempunyai pertimbangan dalam memilih transportasi apa yang akan dibangun dan digunakan sesuai tujuannya. Kebijakan dalam pemilihan moda transportasi ditentukan oleh tingkatan kelas layanan yang diberikan (sesuai dengan hukum ekonomi) dalam pemenuhan kaidah adanya hukum penawaran dan permintaan (Zhang \& Monden, 2003). Ketidakpuasan dari suatu moda transportasi dalam memenuhi kaidah penawaran dan permintaan akan menghasilkan keputusan baik dari pemerintah maupun masyarakat untuk beralih ke moda transportasi lainnya.

Berdasarkan data Statistik Dinas Perhubungan tahun 2014, terdapat tren kenaikan penumpang kereta api sepanjang tahun 2010-2014. Pada tahun 2010-2014, rata-rata penumpang kereta api di Pulau Jawa mengalami kenaikan sebesar 8,98\%. Selain itu, kajian proyeksi studi dari Direktorat Jenderal Perkeretaapian (2006) juga menunjukkan bahwa masyarakat di Jawa Tengah memiliki kecenderungan menggunakan kereta api untuk melakukan perjalanan dengan tren kenaikan 12,8\% dari tahun 2004 hingga 2009. Di samping itu, antara tahun 2009 hingga 2019 diproyeksikan bahwa penumpang kereta api mengalami kenaikan mencapai 31,9\%. Data ini menunjukkan bahwa antusiasme masyarakat sebagai pengguna moda transportasi kereta umum senantiasa meningkat. Melihat kondisi tersebut, terdapat peluang untuk melakukan reaktivasi pada jalur-jalur yang sudah ditutup. Dengan adanya kebijakan reaktivasi, masyarakat sebagai pengguna jasa akan dihadapkan pada pilihan alternatif moda transportasi. Masyarakat sebagai pengguna dapat memilih moda sesuai preferensi, kebutuhan dan jenis moda apa yang dianggap menguntungkan. Melalui intervensi pemerintah dan dengan melihat preferensi masyarakat akan dapat dilihat apakah masyarakat akan tetap menggunakan moda transportasi berbasis jalan raya atau memilih beralih naik kereta api. Begitu pula dengan pemerintah, yang mempunyai peran sebagai penyedia jasa transportasi yang dihadapkan pada prioritas pengembangan transportasi yang disesuaikan dengan kebutuhan dan permintaan masyarakat.

Berbagai studi mengenai faktor yang mempengaruhi preferensi penggunaan transportasi publik telah banyak dibahas. Namun demikian, baru sedikit penelitian yang mengungkapkan mengenai preferensi masyarakat terhadap kebijakan reaktivasi jalur kereta api dan sikap pemerintah menanggapi kebutuhan pengguna kereta api yang senantiasa meningkat. Untuk itu, tujuan penelitian adalah untuk mengkaji preferensi masyarakat dan sikap pemerintah terkait kebijakan reaktivasi jalur rel lintas Semarang - Yogyakarta. Penelitian ini tidak hanya membahas mengenai preferensi masyarakat terhadap kebijakan reaktivasi moda transportasi kereta api namun juga membahas dari sudut pandang pemerintah selaku pemegang kebijakan reaktivasi jalur rel lintas Semarang - Ambarawa Magelang - Yogyakarta. Pendekatan kajian dari sudut masyarakat sebagai pengguna jasa transportasi dan pemerintah sebagai pemilik kebijakan perlu diungkap agar dapat terlihat kesesuaian kebijakan dengan harapan masyarakat.

\section{Metode Penelitian}

Penelitian ini menggunakan metode kombinasi antara metode penelitian kuantitatif dan kualitatif. Metode penelitian kuantitatif digunakan untuk meneliti preferensi masyarakat terkait pemilihan moda transportasi. Sedangkan metode penelitian kualitatif digunakan untuk meneliti sikap pemerintah terkait pemilihan moda tranportasi beserta pendapat ahli. Dalam penelitian terkait dengan preferensi masyarakat, teknik sampling yang digunakan adalah Stratified Random Sampling. Sedangkan terkait dengan persepsi pemerintah, teknik sampling yang digunakan adalah Purposive Sampling. 
Survey untuk mengetahui preferensi masyarakat terhadap kebijakan reaktivasi kerata api dilakukan kepada 100 orang pengguna dan pelaku perjalanan Semarang-Yogyakarta minimal 1 kali dalam sebulan. Kemudian sebaran pilihan moda yang digunakan untuk melakukan perjalanan tersebut adalah 14 orang pengguna mobil/ travel, 35 orang pengguna bus AC, 20 orang pengguna bus ekonomi, dan 31 orang pengguna sepeda motor. Adapun variabel yang digunakan adalah waktu tempuh, aksesibilitas, biaya perjalanan dan sikap kualitatif (kenyamanan, keamanan dan keselamatan). Dalam melihat persepsi ataupun yang menjadi sikap pemerintah terhadap kebijakan reaktivasi serta terhadap keinginan masyarakat (preferensi) tersebut, peneliti mewawancarai beberapa instansi yang mempunyai keterkaitan dengan kebijakan tersebut meliputi Bagian Perencanaan dan Subdit Jaringan Direktorat Jenderal Perkeretaapian serta Dishubkominfo dan Bappeda Provinsi Jawa Tengah. Adapun wawancara tersebut kemudian dikoding untuk memudahkan dalam menganalisis persepsi pemerintah tersebut.

Analisis preferensi masyarakat menggunakan variabel waktu tempuh perjalanan dengan indikator lama tempuh perjalanan, ketepatan waktu, dan kepastian waktu perjalanan (Kanafani, 1983; Polat, 2012). Analisis sikap pemerintah terhadap preferensi masyarakat terkait kebijakan reaktivasi menggunakan variabel aksesibilitas (kemudahan mendapat moda dan pencapaian tempat tujuan), biaya perjalanan, dan sikap kualitatif (kenyamanan, keselamatan, keamanan) (Dagun, 2006; Albalate \& Bel, 2010; Souche, 2010; Shuai \& Haiying, 2011). Untuk menganalisis preferensi masyarakat, digunakan analisis skoring untuk melakukan pembobotan pada variabel yang dipilih masyarakat yang kemudian dilakukan analisis preferensi untuk menilai preferensi yang dihasilkan masyarakat tersebut, serta analisis crosstab guna melihat keterkaitan hubungan antara preferensi masyarakat dengan faktor-faktor indikator yang dijadikan pertimbangan dalam membentuk preferensi masyarakat. Kemudian untuk menganalisis sikap pemerintah terkait implementasi kebijakan reaktivasi, digunakan analisis deskriptif kualitatif. Setelah itu, hasil analisis yang diperoleh dari preferensi masyarakat terkait pemilihan moda transportasi kemudian dikonfirmasikan dengan hasil diperoleh dari sikap pemerintah sebagai pembuat kebijakan dan penyedia infrastruktur transportasi untuk melihat ada tidaknya kesesuaian antara preferensi masyarakat sebagai pengguna moda transportasi dan sikap pemerintah sebagai pembuat kebijakan dan penyedia moda transportasi tersebut melalui analisis kesenjangan atau gap.

\section{Gambaran Umum}

Angkutan penumpang di Jawa Tengah sampai saat ini masih didominasi oleh angkutan berbasis jalan raya. Penggunaan angkutan kereta api di Provinsi Jawa Tengah hanya sekitar $\pm 1 \%$. Sementara itu, penggunaan kendaraan pribadi untuk mobilitas masih mendominasi dengan besaran $71 \%$ berbanding 29\% penggunaan angkutan umum (Direktorat Jenderal Perkeretaapian, 2006).

Kondisi serupa juga terjadi pada ruas jalan nasional yang menghubungkan Semarang - Yogyakarta. Hal ini berakibat pada beban kepadatan jalan raya yang semakin bertambah dan mengakibatkan kemacetan di beberapa ruas jalan pada Semarang - Yogyakarta. Berdasarkan tabel volume capacity ratio tahun 2006, proyeksi beberapa ruas jalan di sepanjang Semarang - Yogyakarta sudah mengalami kepadatan. Hal tersebut seperti yang disajikan pada Tabel 1. 
Tabel 1. Nilai Volume Capacity Ratio

\begin{tabular}{lcccccc}
\hline Nama Ruas & $\mathbf{2 0 0 1}$ & $\mathbf{2 0 0 6}$ & $\mathbf{2 0 0 7}$ & $\mathbf{2 0 0 9}$ & $\mathbf{2 0 1 4}$ & $\mathbf{2 0 1 9}$ \\
\hline Semarang - Bawen & 0,806 & 0,890 & 0,935 & 1,200 & 1,539 & 1,974 \\
Bawen - Pringsurat (Smb) & 0,705 & 0,779 & 0,819 & 1,051 & 1,348 & 1,729 \\
Pringsurat - Bawen (Kdt) & 0,446 & 0,493 & 0,518 & 0,664 & 0,852 & 1,092 \\
Secang - Pringsurat & 0,615 & 0,680 & 0,714 & 0,916 & 1,175 & 1,507 \\
Magelang - Secang & 0,729 & 0,806 & 0,847 & 1,086 & 1,393 & 1,787 \\
Keprekan - Batas Yogya & 0,500 & 0,552 & 0,581 & 0,744 & 0,954 & 1,224 \\
Magelang - Salaman & 0,748 & 0,827 & 0,869 & 1,115 & 1,430 & 1,835 \\
Keprekan - Salaman & 0,374 & 0,413 & 0,434 & 0,557 & 0,715 & 0,916 \\
Muntilan - Klangon (Batas. D.I. Yogyakarta) & 0,456 & 0,503 & 0,529 & 0,679 & 0,872 & 1,120 \\
Magelang - Kaliangkrik & 0,133 & 0,147 & 0,155 & 0,199 & 0,255 & 0,327 \\
\hline
\end{tabular}

Sumber: Direktorat Jenderal Perkeretaapian, 2006

Berdasarkan tabel volume capacity ratio tersebut, ruas Semarang - Bawen sudah mengalami kepadatan dan pada tahun 2014 diproyeksikan akan mengalami kemacetan yang parah. Menyikapi hal tersebut pemerintah mempunyai rencana mereaktivasi jalur rel lintas Semarang - Yogyakarta, untuk membantu mengurangi beban kepadatan jalan tersebut. Adapun rencana tersebut sudah tercantum pada Rencana Induk Perkeretaapiaan Nasional (RIPNas) tahun 2011. Rencana pengembangan tersebut juga dicanangkan dalam SISTRANAS, untuk jaringan jalan rel Provinsi Jawa Tengah disajikan pada Tabel 2.

Tabel 2. Rencana Pengembangan Jaringan Jalan Rel Via Jawa Tengah

\begin{tabular}{|c|c|c|c|c|}
\hline \multirow[b]{2}{*}{ No } & \multirow[b]{2}{*}{ Nama Ruas } & \multicolumn{3}{|c|}{ Peran } \\
\hline & & Tahun 2006 & Jangka Pendek & $\begin{array}{c}\text { Jangka } \\
\text { Menengah }\end{array}$ \\
\hline \multirow[t]{4}{*}{ A. } & Gelang Jawa & & & \\
\hline & Jakarta-Cikampek-Jatibarang- & Lintas utama & Lintas utama & Lintas utama \\
\hline & Cirebon-Semarang-Bojonegoro- & & & \\
\hline & Surabaya & & & \\
\hline \multirow[t]{14}{*}{ B. } & Sirip Jawa & & & \\
\hline & Cilacap-Maos & Lintas cabang & Lintas cabang & Lintas cabang \\
\hline & Cirebon-Prupuk-Purwokerto-Kroya & Lintas utama & Lintas utama & Lintas utama \\
\hline & Tegal-Prupuk & Lintas cabang & Lintas cabang & Lintas cabang \\
\hline & Wonosobo-Purwokerto & Lintas cabang & Lintas cabang & Lintas cabang \\
\hline & Purworejo_kutoarjo & Lintas cabang & Lintas cabang & Lintas cabang \\
\hline & Semarang-Magelang-Yogyakarta & Lintas utama & Lintas utama & Lintas utama \\
\hline & Parakan-Secang & Lintas cabang & Lintas cabang & Lintas cabang \\
\hline & Wonogiri-Surakarta & Lintas cabang & Lintas cabang & Lintas cabang \\
\hline & Kedungjati-Gundih & Lintas cabang & Lintas cabang & Lintas cabang \\
\hline & Gambringan-Surakarta & Lintas cabang & Lintas cabang & Lintas cabang \\
\hline & Cepu-Blora-Winosari-Purwodadi- & Lintas cabang & Lintas cabang & Lintas cabang \\
\hline & Demak-Kudus-Juwana-Rembang- & & & \\
\hline & Lasem-Jatirogo-Bojonegoro & & & \\
\hline
\end{tabular}




\section{Hasil dan Pembahasan}

\section{Analisis Preferensi Masyarakat terhadap Kebijakan Reaktivasi Moda Kereta Api}

Hasil survey terhadap responden menunjukkan bahwa sebanyak 44\% responden memilih biaya perjalanan sebagai faktor yang menjadi pertimbangan mereka untuk memilih kereta api. Kemudian $27 \%$ responden memilih waktu tempuh sebagai faktor yang menjadi pertimbangan preferensi mereka, diikuti oleh $18 \%$ responden yang memilih aksesibilitas dalam mendasari pertimbangan keputusan mereka, dan ada $11 \%$ responden yang memilih sikap kualitatif menjadi pertimbangan preferensi mereka. Adapun sebaran preferensi masyarakat tersebut seperti yang disajikan pada Gambar 1.

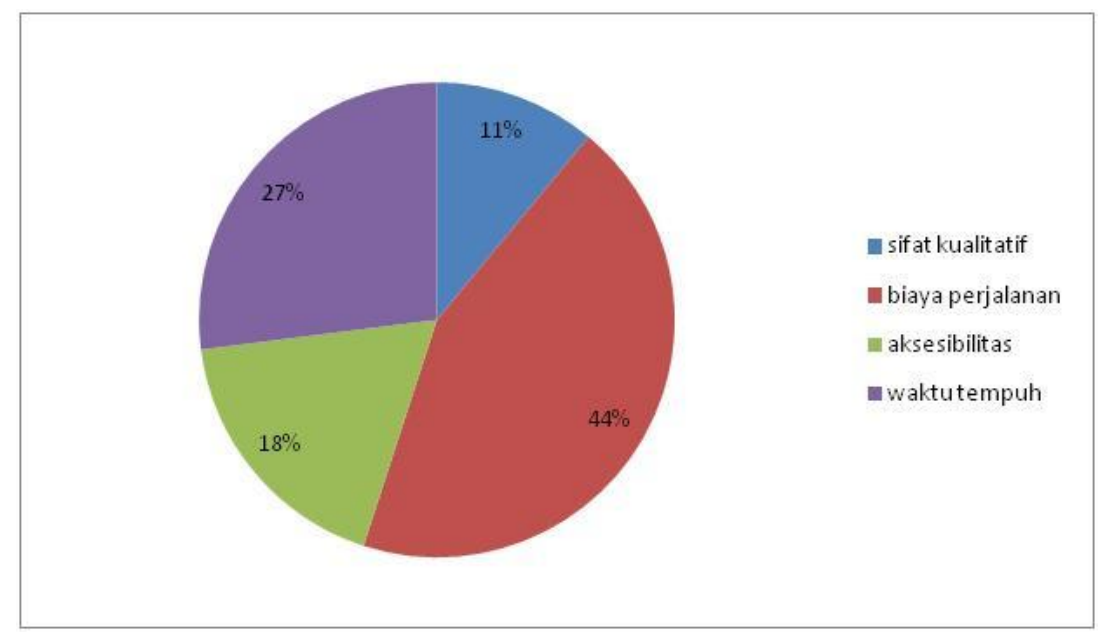

\section{Gambar 1. Variabel Preferensi Masyarakat dalam Pemilihan Moda Kereta Api}

Berdasarkan analisis tabulasi silang (crosstab) sebagaimana tersaji di Tabel 3, diperoleh hasil bahwa Chi square hitung $(44,462)$ lebih dari nilai Chi square tabel (16.919) serta nilai signifikansi 0,000 yang menunjukkan kurang dari 0,005 yang menunjukkan bahwa faktor-faktor indikator di atas (sifat kualitatif, biaya perjalalan, aksesibilitas, dan waktu tempuh) memiliki keterhubungan yang sangat kuat dalam membentuk preferensi masyarakat dalam memilih untuk beralih naik kereta api.

Tabel 3. Chi Square Test Moda Transportasi dengan Variabel Indikator

\begin{tabular}{lccc}
\hline & Value & df & Asymp. Sig. (2-sided) \\
\hline Pearson Chi-Square & $44.462^{\mathrm{a}}$ & 9 & .000 \\
Likelihood Ratio & 54.996 & 9 & .000 \\
Linear-by-Linear Association & .975 & 1 & .323 \\
N of Valid Cases & 100 & & \\
\hline
\end{tabular}

Namun demikian, keterhubungan masing-masing faktor tersebut tidak mengikat. Seperti untuk pengguna mobil atau travel bahwa faktor biaya tidak menjadi pertimbangan utama mereka untuk memilih kereta api, melainkan faktor waktu tempuh ataupun sikap kualitatif. Hal ini dikarenakan kemampuan membayar mereka yang lebih tinggi dibandingkan moda transportasi jalan yang lainnya. Untuk pengguna bus ekonomi, faktor 
biaya menjadi pertimbangan utama. Pengguna bus ekonomi memiliki kemampuan membayar yang paling rendah diantara moda transportasi lain. Pengguna bus ekonomi memilih faktor biaya yang memiliki keterhubungan dengan preferensi mereka. Adapun pengguna sepeda motor menjadikan faktor biaya dan waktu tempuh sebagai pertimbangan yang memiliki keterkaitan terhadap preferensi mereka.

Selain hal tersebut, berdasarkan hasil wawancara dan analisis juga diperoleh kecenderungan preferensi penumpang moda transportasi berbasis jalan raya terhadap moda kereta api seperti yang disajikan pada Tabel 4. Hampir semua penumpang/ pengguna moda memilih variabel biaya perjalanan yang mempunyai hubungan keterkaitan dengan preferensi mereka naik kereta api. Hanya penumpang/ pengguna mobil/ travel yang memilih variabel sikap kualitatif dan waktu tempuh yang mempunyai hubungan keterkaitan dengan preferensi mereka naik kereta api.

Tabel 4. Sintesis Kecenderungan Preferensi Penumpang atau Pengguna Moda Transportasi Terhadap Moda Kereta Api

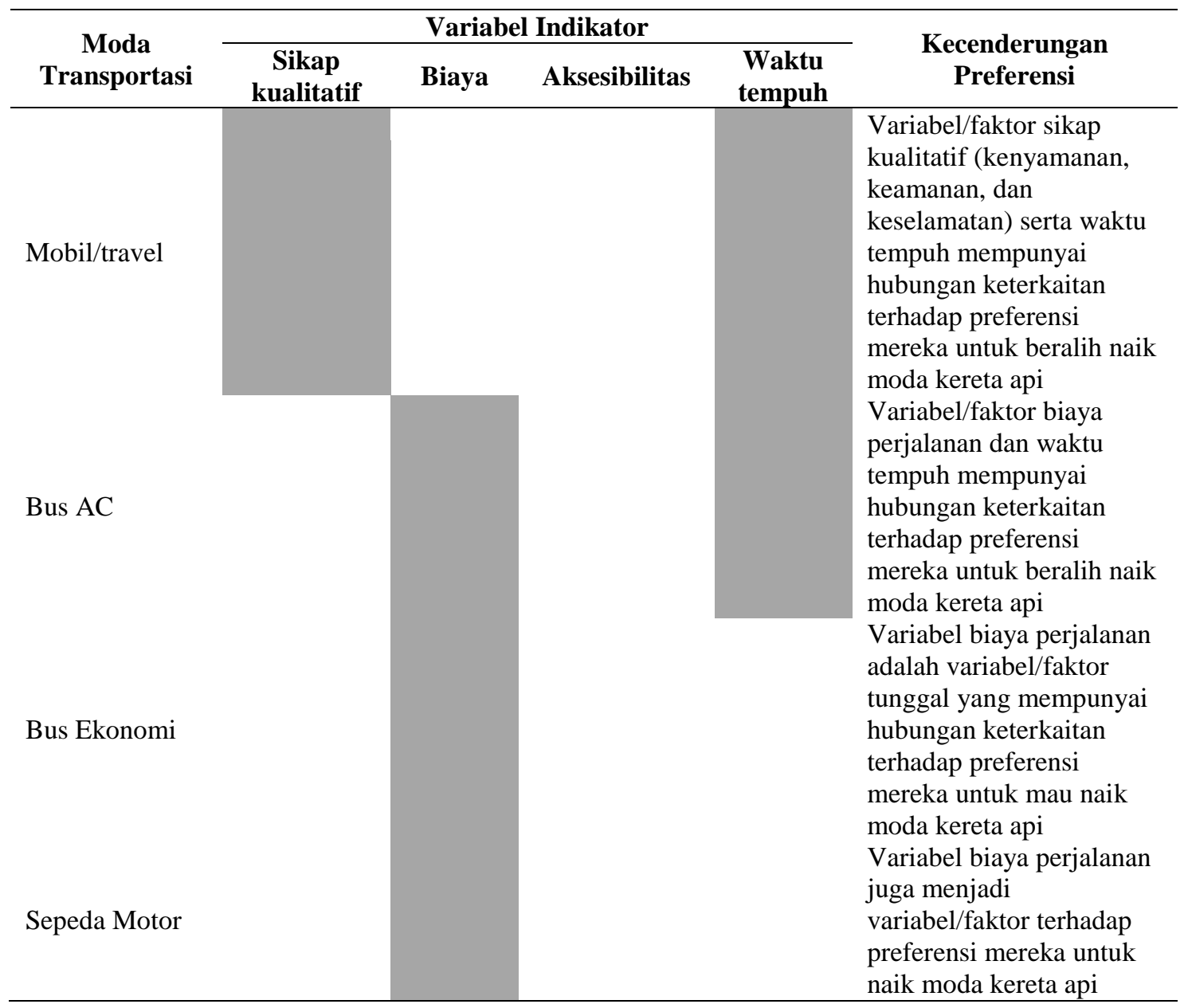

Keterangan: = Variabel penentu preferensi masing-masing pengguna moda transportasi 


\section{Analisis Pemerintah terhadap Preferensi Masyarakat dan Kesiapan Pengimplementasian Kebijakan Reaktivasi Moda Kereta Api}

Berdasarkan hasil wawancara dengan pihak pemerintah, baik itu pemerintah pusat maupun pihak pemerintah provinsi, diperoleh informasi bahwa pemerintah memang sudah mempunyai rencana untuk menghidupkan kembali/mereaktivasi jalur rel lintas Semarang Yogyakarta. Adapun pemilihan moda kereta api sebagai alternatif moda yang dipilih, didasari fakta bahwa moda kereta api ini dahulu pernah dioperasikan untuk melayani pergerakan penumpang dan barang lintas Semarang - Yogyakarta. Hingga kini, trase ataupun lintas tersebut masih ada walaupun sebagian besar sudah mengalami alih fungsi. Namun begitu, moda kereta api memiliki kelebihan-kelebihan bila dibandingkan dengan moda transportasi berbasis jalan raya.

Pemerintah juga telah melakukan kajian ataupun studi perencanaan. Adapun studi perencanaan yang telah dilakukan oleh pemerintah sebagai tahap awal kebijakan tersebut adalah "Studi Kelayakan Menghidupkan Kembali Jalan Kereta Api lintas Yogyakarta Magelang Tahun 2006". Dengan adanya rencana pemerintah untuk mereaktivasi lintas Semarang - Yogyakarta ini, pengoperasian moda kereta api tidak hanya bertujuan mengangkut penumpang ke tempat tujuan di Semarang ataupun Yogyakarta, tetapi juga bisa dioperasikan sebagai angkutan wisata, yang membawa keuntungan ekonomis bagi daerah tersebut.

Pengoperasian moda kereta api tidak hanya bertujuan mengangkut penumpang ke tempat tujuan di Semarang ataupun Yogyakarta, tetapi juga bisa dioperasikan sebagai angkutan wisata yang membawa keuntungan ekonomis bagi daerah tersebut. Akan tetapi, implementasi dari kebijakan tersebut ternyata tidak dapat dengan segera dilaksanakan. Pada saat ini, kondisi jalur eksisting sudah berubah menjadi pemukiman warga, ruko, perkantoran bahkan menjadi jalan nasional sehingga membuat kebijakan reaktivasi ini menjadi semakin sulit untuk diimplementasikan. Pemerintah juga telah berusaha melakukan upaya-upaya yang diperlukan untuk penyediaan lahan. Upaya pendekatan ataupun sosialisasi kepada masyarakat dilakukan dengan maksud memberikan pemahaman kepada masyarakat bahwa lahan yang akan dibangun adalah lahan milik pemerintah. Dengan melihat segala permasalahan terkait penyediaan lahan tersebut, pemerintah provinsi juga telah memberikan usulan kepada pemerintah pusat untuk menggeser trase/ lintas eksisting sehingga dapat lebih memudahkan untuk penyediaan lahan. Tetapi hal ini masih belum dapat serta merta dilaksanakan, mengingat pemerintah pusat, terkait usulan tersebut, masih harus berkoordinasi dengan pemerintah daerah, serta melakukan studi perencanaan kembali guna pengimplementasian kebijakan reaktivasi tersebut. Di samping itu, juga terdapat kendala terkait biaya ataupun anggaran. Adapun indikasi anggaran yang sudah direncanakan untuk reaktivasi ini oleh pemerintah tersebut sebesar kurang lebih Rp 681 Milyar (Hasil Wawancara Kasubag Rencana Bagian Perencanaan Ditjen Perkeretaapian, 2015). Fokus pembangunan transportasi yang secara politis saat ini difokuskan pada wilayah Indonesia bagian timur juga menjadi kendala tersendiri. Pemerintah pusat sendiri, pada tahun 2015-2019 sudah merencanakan untuk melaksanakan kegiatan reaktivasi di berbagai daerah di Pulau Jawa. Akan tetapi, terjadinya suksesi kepemimpinan negara ini, membuat pemerintah merevisi arah kebijakan pengembangan perkeretaapian. Adapun pergeseran fokus pembangunan perkeretaapian disesuaikan dengan arah kebijakan yang ditetapkan oleh pemerintahan yang baru tersebut. Hasil wawancara DENGAN Kasubag Perencanaan Ditjen Perkeretaapian Kemenhub (2015) mengungkapkan bahwa fokus pengembangan untuk reaktivasi ini baru akan dilaksanakan pada tahun 2020-2024. Arah pengembangan perkeretaapian pada tahun 2014-2019, difokuskan pada proyek pembangunan double track lintas selatan Jawa dan Pembangunan Trans Sumatera, Sulawesi dan Papua. Sehingga anggaran yang ada juga dialihkan terhadap pengembangan tersebut Dengan adanya permasalahan di atas, tentunya membutuhkan 
suatu perencanaan ulang terkait tahapan-tahapan pengimplementasian kebijakan reaktivasi tersebut.

Terkait preferensi masyarakat, pemerintah bersikap bahwa perlu terlebih dahulu memperhitungkan biaya pengoperasian moda transportasi kereta api tersebut. Adanya skema pemberian subsidi (PSO) guna memenuhi keinginan masyarakat akan tarif kereta yang terjangkau. Selain itu, Pemerintah sendiri telah melaksanakan upaya perbaikan yang mendukung sikap kualitatif tersebut. Hal ini dapat dilihat dari upaya pemerintah yang mendorong PT.KAI untuk membenahi dan meningkatkan kualitas pelayanannya. Kondisi moda transportasi saat ini, hampir seluruh kelas layanan kereta api sudah dilengkapi fasilitas pendingin udara. Dahulu untuk kelas bisnis maupun ekonomi tidak dilengkapi fasilitas pendingin udara. Kemudian pemberlakuan aturan satu tiket untuk satu kursi penumpang (tidak tersedia tiket berdiri lagi). Hal tersebut menambah unsur kenyamanan ketika menaiki kereta api. Ditambah lagi saat ini, seluruh pintu kereta penumpang tertutup selama melakukan perjalanan. Kemudian terkait usulan masyarakat akan adanya penyediaan feeder sebagai moda yang memberikan kemudahan untuk aksesibilitas masyarakat, tanggapan pemerintah sendiri, mendukung penyediaan fasilitas tersebut. Hal ini dikarenakan ketersediaan tersebut akan membantu terwujudnya integrasi antar moda yang ada (Hasil Wawancara Kasie Perkeretaapian Dishubkominfo Prov. Jateng 2015). Penjelasan ini menunjukkan bahwa ada keinginan masyarakat yang menjadikan faktor kualitatif (kenyamanan, keamanan, dan keselamatan) sebagai variavel pertimbangan dalam beralih naik kereta api. Melihat permasalahan yang ada, harapan masyarakat untuk dapat naik kereta api dalam melakukan perjalanan lintas Semarang-Yogyakarta belum dapat terlaksana dalam waktu dekat karena masih banyak tahapan-tahapan yang harus dilaksanakan sebelum akhirnya sampai pada tahapan konstruksi, kemudian dilanjutkan dengan pengoperasian kereta api.

\section{Analisa GAP Preferensi Masyarakat dan Sikap Pemerintah terkait Rencana Pengimplemetasian Kebijakan Reaktivasi Moda Kereta Api}

Dari hasil survei kemudian diperoleh apa yang menjadi preferensi dari masingmasing pengguna moda transportasi jalan raya. Kemudian preferensi tersebut dikomparasikan/ diperbandingkan dengan apa yang menjadi sikap pemerintah. Adapun komparasi antara apa yang menjadi preferensi masyarakat dengan apa yang menjadi sikap pemerintah seperti yang disajikan pada Tabel 5. Berdasarkan penjelasan yang diuraikan pada Tabel 5 diperoleh informasi, terkait faktor sikap kualitatif (kenyamanan, keamanan, dan keselamatan) dan juga aksesibilitas, dapat disimpulkan bahwa apa yang menjadi keinginan masyarakat, juga sama dengan apa yang menjadi persepsi ataupun sikap pemerintah. Pada variabel/ faktor sikap kualitatif, responden pada penelitian ini mayoritas sudah pernah memiliki pengalaman naik moda kereta api. Hal ini tentunya menjadi suatu acuan bagi responden terkait gambaran kereta api beserta kelas layanannya saat ini.

Pengalaman pernah naik kereta api membuat mayoritas responden mengatakan bahwa dengan naik kereta api, keinginan mereka akan transportasi yang nyaman, aman dan mempunyai keselamatan yang baik dapat terpenuhi. Dari sudut pandang pemerintah, pemerintah juga telah berupaya meningkatkan pelayanan KA bersama PT.KAI sebagai operator dengan melakukan berbagai kebijakan untuk meningkatkan kualitas layanan kereta api. Akan tetapi, penerapan kualitas layanan tersebut tidaklah serupa di setiap jalur kereta api. Pemerintah akan mengadakan studi atau evaluasi terlebih dahulu sebelum menentukan kelas layanan KA yang akan melayani pada lintas Semarang - Yogyakarta dan hal ini mempunyai keterkaitan dengan biaya tarif tiket yang akan diberlakukan.

Selain variabel sikap kualitatif, pada variabel aksesibilitas juga memiliki kesamaan dengan apa yang menjadi keinginan masyarakat dengan apa yang menjadi sikap pemerintah. Permintaan masyarakat akan kemudahan untuk dapat mengakses moda kereta 
api dengan penyediaan feeder sebagai angkutan dari dan menuju stasiun juga didukung oleh sikap pemerintah. Bahkan pemerintah berharap dengan adanya feeder tersebut dapat mewujudkan integrasi antar moda.

Perbedaan ataupun kesenjangan antara keinginan masyarakat yang menjadi preferensi masyarakat dengan sikap pemerintah berdasarkan ditunjukkan oleh variabel waktu tempuh dan biaya. Terkait keinginan masyarakat yang menginginkan waktu tempuh perjalanan kereta api yang bisa menyamai dengan rata-rata waktu tempuh perjalanan masyarakat saat ini, yaitu membutuhkan waktu 3 jam, masih menjadi suatu pertimbangan bagi pemerintah. Pemerintah masih belum bisa memberikan informasi terkait waktu tempuh perjalanan KA tersebut. Terkait biaya perjalanan, adanya keinginan masyarakat bahwa biaya perjalanan ataupun tarif tiket kereta api bisa lebih rendah/ murah dibandingkan dengan biaya perjalanan yang mereka keluarkan saat ini. Menanggapi keinginan masyarakat itu, pemerintah menyatakan belum bisa menentukan besaran tarif tiket kereta api lintas Semarang - Yogyakarta. Hal ini dikarenakan masih perlu adanya survei dan evaluasi ATP/WTP untuk mengetahui daya beli masyarakat.

Berdasarkan uraian di atas, apa yang menjadi preferensi masyarakat, yang tercakup dalam variabel tersebut, juga menjadi pertimbangan pemerintah dalam mengimplementasikan kebijakan reaktivasi tersebut. Pemenuhan dari variabel yang membentuk preferensi penumpang tersebut sejalan dengan apa yang menjadi ukuran dalam pelayanan transportasi, dimana variabel terkait waktu tempuh dan biaya perjalanan masih perlu diperhatikan. Hal ini mendukung pernyataan Matas (2004), Crotte (2008), Souche (2010), Albalate dan Bel (2010), serta Polat (2012) bahwa perilaku pengguna jasa transportasi ditentukan oleh intervensi pemerintah, pelayanan yang dibeirkan, biaya perjalanan, dan pola perjalanan. Warpani (1990) yang mengatakan bahwa ukuran pelayanan terbaik adalah apabila pelayanan angkutan tersebut memenuhi kriteria aman, nyaman, cepat dan murah. Pengimplemetasian kebijakan reaktivasi merupakan solusi yang tepat untuk membantu mengurangi beban kepadatan jalan raya lintas Semarang Yogyakarta. Pengimplemetasian kebijakan reaktivasi merupakan solusi yang tepat untuk membantu mengurangi beban kepadatan jalan raya lintas Semarang - Yogyakarta. Dengan segala keunggulan serta karakteristik yang melekat pada moda transportasi kereta api, pemerintah hendaknya memiliki kesiapan serta mendukung preferensi masyarakat guna mendorong segera terwujudnya implementasi dari kebijakan reaktivasi tersebut. 
Tabel 5. Komparasi atau Perbandingan Preferensi Pengguna atau Penumpang Moda Transportasi Jalan Raya dengan Sikap Pemerintah

\begin{tabular}{|c|c|c|c|c|}
\hline $\begin{array}{l}\text { Variabel } \\
\text { Indikator }\end{array}$ & $\begin{array}{c}\text { Moda } \\
\text { Transportasi }\end{array}$ & Preferensi Masyarakat & Sikap Pemerintah & Keterangan \\
\hline \multirow[t]{2}{*}{$\begin{array}{l}\text { Sikap Kualitatif } \\
\text { (Kenyamanan, } \\
\text { Keamanan, dan } \\
\text { Keselamatan) }\end{array}$} & Mobil/Travel & $\begin{array}{l}\text { - } \text { Bagi pengguna/penumpang mobil/travel, } \\
\text { pemenuhan dari sikap kualitatif } \\
\text { (kenyamanan, keamanan, dan } \\
\text { keselamatan) merupakan variabel yang } \\
\text { harus terpenuhi ketika melakukan } \\
\text { perjalanan dengan kereta api. } \\
\text { - Preferensi masyarakat bahwa kereta api } \\
\text { sudah nyaman, aman, keselamatan } \\
\text { tinggi. Hal ini didasari karena hampir } \\
\text { semua responden } 96 \% \text { pernah naik kereta } \\
\text { api. Pengalaman tersebut menjadi dasar } \\
\text { pembanding mereka akan variabel } \\
\text { kenyaman, keamanan, dan keselamatan } \\
\text { dengan moda kereta api }\end{array}$ & $\begin{array}{l}\text { - Penyediaan layanan kereta } \\
\text { api, terkait dengan sikap } \\
\text { kualitatif, disesuaikan dengan } \\
\text { kelas layanan KA itu sendiri. } \\
\text { - Pengoperasian kelas KA yang } \\
\text { melayani lintas tersebut akan } \\
\text { ditetapkan setelah melalui } \\
\text { studi ataupun evaluasi. }\end{array}$ & $\begin{array}{l}\text { - Terkait preferensi masyarakat akan variabel } \\
\text { sikap kualitatif tersebut, juga menjadi } \\
\text { serupa dengan kebijakan pemerintah. } \\
\text { - Hal ini dapat dilihat dari upaya pemerintah } \\
\text { mendorong perbaikan pelayanan oleh } \\
\text { PT.KAI. } \\
\text { - Kondisi saat ini, hampir semua kelas KA } \\
\text { dilengkapi fasilitas pendingin udara, } \\
\text { peraturan satu tiket satu kursi,dan } \\
\text { tertutupnya pintu kereta selama perjalanan. }\end{array}$ \\
\hline & $\begin{array}{l}\text { Bus AC } \\
\text { Bus Ekonomi } \\
\text { Sepeda Motor }\end{array}$ & & & \\
\hline Biaya & Mobil/Travel & & & - Preferensi masyarakat memilih KA terkait \\
\hline Perjalanan & Bus Ekonomi & $\begin{array}{l}\text { Penumpang bus AC, memilih biaya } \\
\text { perjalanan, didasari pengalaman mereka } \\
\text { naik kereta api pada lintas pelayanan di } \\
\text { regional Jawa Tengah, yang lebih murah } \\
\text { dibandingkan moda transportasi berbasis } \\
\text { jalan raya. } \\
\text { Bagi pengguna/penumpang bus ekonomi, } \\
\text { biaya perjalanan adalah faktor paling utama } \\
\text { yang membuat mereka mau beralih naik } \\
\text { kereta api. Hal ini, didasari pada asumsi } \\
\text { bahwa pengguna/penumpang bus ekonomi } \\
\text { mempunyai kemapuan membayar yang } \\
\text { paling kecil diantara moda transportasi lain. }\end{array}$ & $\begin{array}{l}\text { - Pemerintah terkait biaya, } \\
\text { berfokus pada anggaran yang } \\
\text { dikeluarkan untuk } \\
\text { pembangunan reaktivasi } \\
\text { - Biaya yang dikeluarkan untuk } \\
\text { pengoperasian kereta api juga } \\
\text { menjadi pertimbangan dalam } \\
\text { penetuan tarif. } \\
\text { - Ada skema pemberian subsidi } \\
\text { (PSO) supaya dapat } \\
\text { terjangkau masyarakat }\end{array}$ & $\begin{array}{l}\text { dengan tarif KA yang murah/lebih murah } \\
\text { dibanding moda lainnya. } \\
\text { - Pemerintah melihat biaya, tidak hanya } \\
\text { sebatas tarif, tetapi keseluruhan biaya } \\
\text { infrastruktur, pengoperasian sarana, dan } \\
\text { biaya lainnya, baru kemudian bisa } \\
\text { menetapkan tarif yang sesuai untuk lintas } \\
\text { tersebut. } \\
\text { - Ada kebijakan pemberian subsidi (PSO), hal } \\
\text { ini dilakukan setelah adanya evaluasi } \\
\text { terhadap kemampuan membayar masyarakat } \\
\text { dan tingkat okupansi penumpang KA. }\end{array}$ \\
\hline
\end{tabular}


200 Kajian Preferensi Masyarakat dan Sikap Pemerintah Terkait Reaktivasi...

\begin{tabular}{|c|c|c|c|c|}
\hline $\begin{array}{l}\text { Variabel } \\
\text { Indikator }\end{array}$ & $\begin{array}{c}\text { Moda } \\
\text { Transportasi }\end{array}$ & Preferensi Masyarakat & Sikap Pemerintah & Keterangan \\
\hline \multirow[b]{2}{*}{ Aksesibilitas } & Sepeda Motor & $\begin{array}{l}\text { Bagi pengguna sepeda motor, biaya } \\
\text { perjalanan juga menjadi faktor utama untuk } \\
\text { mau beralih naik kereta api. Apabila } \\
\text { biaya/tarif tiket kereta api jauh lebih mahal, } \\
\text { mereka tetap akan menggunakan sepeda } \\
\text { motor untuk melakukan perjalanan. }\end{array}$ & & \\
\hline & $\begin{array}{l}\text { Mobil/Travel } \\
\text { Bus AC } \\
\text { Bus Ekonomi } \\
\text { Sepeda Motor }\end{array}$ & & & \multirow{4}{*}{$\begin{array}{l}\text { Berdasarkan hasil survei, diperoleh informasi } \\
\text { bahwa baik apa yang menjadi preferensi } \\
\text { masyarakat, ataupun apa yang menjadi sikap } \\
\text { pemerintah, terkait layanan feeder, yang } \\
\text { digunakan untuk memudahkan aksesibilitas } \\
\text { masyarakat menuju stasiun adalah serupa } \\
\text { - Apa yang menjadi preferensi masyarakat } \\
\text { agar waktu tempuh KA sama dengan waktu } \\
\text { tempuh perjalanan moda sekarang, masih } \\
\text { belum menjadi suatu yang dapat dipastikan } \\
\text { pemerintah, dikarenakan gradien lahan pada } \\
\text { beberapa ruas, tidak bisa dilewati KA } \\
\text { - Sehingga jalur KA memutar melewati } \\
\text { wilayah yang gradiennya dapat dilewati KA } \\
\text { - Pemerintah masih terus berkoordinasi, } \\
\text { terkait penerapan teknologi dalam } \\
\text { mengatasi permasalahan tersebut. } \\
\text { - Terkait variabel waktu tempuh, reabilitas } \\
\text { ataupun kepastian waktu perjalanan kereta } \\
\text { api dibanding moda transportasi lain lebih } \\
\text { baik. }\end{array}$} \\
\hline \multirow[t]{3}{*}{ Waktu Tempuh } & Mobil/Travel & $\begin{array}{l}\text { Adapun waktu tempuh yang diinginkan } \\
\text { pengguna/penumpang mobil/travel ketika } \\
\text { mau beralih naik kereta api adalah sama } \\
\text { dengan waktu tempuh perjalanan mereka } \\
\text { saat ini, yaitu tiga jam. }\end{array}$ & \multirow{3}{*}{$\begin{array}{l}\text { - Pemerintah menyatakan, } \\
\text { bahwa kereta api seharusnya } \\
\text { bisa lebih cepat dari moda } \\
\text { transportasi sekarang ini } \\
\text { masyarakat gunakan. } \\
\text { - Akan tetapi dengan adanya } \\
\text { beberapa daerah yang } \\
\text { memiliki gradien yang tidak } \\
\text { bisa dilewati oleh kereta api, } \\
\text { membuat jalur kereta api } \\
\text { harus memutar melewati } \\
\text { daerah yang gradiennya dapat } \\
\text { dilewati kereta api. }\end{array}$} & \\
\hline & Bus AC & $\begin{array}{l}\text { Preferensi masyarakat agar waktu tempuh } \\
\text { kereta api sama seperti dengan waktu } \\
\text { tempuh perjalanan dengan menggunakan } \\
\text { moda transportasi sekarang ini mereka } \\
\text { gunakan yang juga sama dengan yang } \\
\text { menjadi preferensi pengguna/penumpang } \\
\text { mobil/travel, yaitu tiga jam. }\end{array}$ & & \\
\hline & $\begin{array}{l}\text { Bus Ekonomi } \\
\text { Sepeda Motor }\end{array}$ & & & \\
\hline
\end{tabular}




\section{Kesimpulan}

Adanya kebijakan pemerintah untuk menghidupkan kembali atau reaktivasi jalur rel lintas Semarang - Yogyakarta bertujuan untuk mengurangi kepadatan di ruas jalan Semarang - Yogyakarta. Meskipun terdapat beragam reaksi dari masyarakat terkait kebijakan tersebut, hasil survey menunjukkan minat yang cukup besar terhadap kemungkinan implementasi kebijakan tersebut. Mayoritas masyarakat menyatakan tertarik untuk beralih menggunakan kereta api. Masyarakat juga memberikan berbagai pertimbangan yang menjadi alasan untuk memilih menggunakan kereta api, yaitu faktor biaya, waktu tempuh (reabilitas/ kecepatan), aksesibilitas dan sikap kualitatif (kenyamanan, keamanan, dan keselamatan). Keempat faktor tersebut merupakan alat yang digunakan oleh masyarakat menjatuhkan pilihan/ preferensi untuk bersedia beralih naik kereta api apabila faktor-faktor tersebut dapat tersedia. Namun demikian, juga masih terdapat perbedaan atau kesenjangan antara keinginan masyarakat yang menjadi preferensi masyarakat dengan sikap pemerintah terkait dengan faktor biaya/ harga tiket yang lebih murah, waktu tempuh yang lebih pasti dan cepat, dan kenyamanan, keamanan, dan keselamatan untuk beralih ke kereta api. Kondisi demikian perlu menjadi pertimbangan pemerintah selaku regulator dalam mengimplementasikan kebijakan tersebut.

Dalam menanggapi keinginan masyarakat tersebut, implementasi kebijakan reaktivasi belum dapat diimplementasikan dalam waktu dekat. Hal ini disebabkan masih adanya beberapa kendala dalam pengimplementasian kebijakan tersebut, seperti pembebasan dan penertiban lahan yang telah mengalami alih fungsi, adanya usulan penggeseran alternatif trase atau lintas baru dari pemerintah daerah, keterbatasan anggaran menjadikan kebijakan tersebut tidak dapat segera direalisasikan, serta perubahan arah fokus pembangunan dikarenakan adanya suksesi kepemimpinan membuat reaktivasi ini masih terus dalam tataran kebijakan pemerintah. Untuk memenuhi keinginan masyarakat, diperlukan berbagai tahapan perencanaan lainnya. Adapun tahapan-tahapan tersebut, seperti studi-studi, koordinasi dengan pihak pemerintah daerah kesiapan lahan dan dukukungan masyarakat, koordinasi dengan pihak PT. KAI terkait penyediaan sarana untuk melayani lintas tersebut, serta berbagai evaluasi sebelum membuat suatu keputusan.

\section{Daftar Pustaka}

Albalate, D., \& Bel, G. (2010). What shapes local public transportation in Europe? Economics, mobility, institutions, and geography. Transportation Research Part E, 46, 775-790. doi:10.1016/j.tre.2009.12.010.

Bosserhoff, D. (2007). Making regional railroads more attractive - research studies in Germany and Patronage characteristics. Journal of Public Transportation, 19(1), 27-58. doi:10.5038/2375-0901.10.1.2

Crotte, A. (2008). Estimation of transport related demand elasticities in mexico city: An application to road user charging (Unpublished master's thesis). Centre for Transport Studies, Department of Civil and Environmental Engineering, Imperial College, United Kingdom.

Dagun, S. (2006). Busway: Terobosan penanganan transportasi jakarta. Jakarta: Pustaka Sinar Harapan.

Direktorat Jenderal Perkeretaapian. (2006). Studi kelayakan menghidupkan kembali jalan kereta api lintas Yogyakarta - Magelang tahun 2006. Jakarta: Direktorat Jenderal Perkeretaapian, Kementerian Perhubungan RI.

Kanafani, A. K. (1983). Tranportation demand analysis. US: Mc.Graw-Hill College.

Matas, A. (2004). Demand and revenue implications of an integrated public transport policy: The case of Madrid. Transport Reviews: A Transnational Transdisciplinary Journal, 24(2), 195-217. doi:10.1080/0144164032000107223.

Li, Z. C., Lam, W. H. K., Wong, S. C., \& Sumalee, A. (2011). Design of a rail transit line for profit maximization in a linear transportation corridor. Procedia Social and Behavioral Sciences, 17, 82-112. doi:10.1016/j.sbspro.2011.04.509. 


\section{Kajian Preferensi Masyarakat dan Sikap Pemerintah Terkait Reaktivasi .. .}

Polat, C. (2012). The demand determinants for urban public transport services: A review of the literature. Journal of Applied Sciences, 12(12), 1211-1231. doi:10.3923/jas.2012.1211.1231.

Shuai, H., \& Haiying, L. (2011). A urban rail transport network carrying capacity calculation method based on the logit model. Proceedings 2011 International Conference on Transportation, Mechanical, and Electrical Engineering (TMEE), 191-194. doi:10.1109/tmee.2011.6199177.

Souche, S. (2010). Measuring the structural determinants of urban travel demand. Transport Policy, 17(3), 127134. doi:10.1016/j.tranpol.2009.12.003.

Vuchic, V. R. (2005). Urban transit: operations, planning and economics. Hoboken, NJ, USA: John Wiley \& Sons.

Warpani, S. (1990). Merencanakan sistem perangkutan. Bandung: Penerbit Institut Teknologi Bandung.

Zhang, J. \& Monden, H. (2003). Transport demand and supply model based on disequilibrium theory. Journal of the Eastern Asia Society for Transportation Studies, 5, 1262-1277. 